\author{
MARÍA ISABEL BALDASARRE \\ CONICET, UNIVERSIDAD NACIONAL DE SAN MARTÍN
}

\title{
Representación y autorrepresentación en el arte argentino: retratos de artistas en la primera mitad del siglo $X X$
}

OS AUTORRETRATOS HAN CONSTITUIDO una parte fundamental en la producción de los artistas de Occidente desde los tiempos modernos. Fueron terrenos de experimentación, al permitir al artista la inmediatez de constituirse en su propio modelo, y medios para demostrar la habilidad lograda por su ejecutante. Pero además, al transformarse el pintor en el sujeto de su representación, estas obras funcionan como metáforas de su poder creativo como artista y del modo en que cada uno, en las coyunturas históricas específicas, entendió y volvió visible su estatus como creador. ${ }^{\mathrm{I}}$

En Argentina, la actividad artística profesional se instituyó tardíamente en comparación con otros países americanos. Sólo hacia finales del siglo XIX comenzaron a gestarse las primeras instituciones y las agrupaciones de artistas, al no existir una academia — como en los casos mexicano o brasileñoque perviviera los tiempos coloniales. En la producción de estos hombres que desde finales del siglo comenzaron a dedicarse al cultivo de las bellas artes, los autorretratos constituyeron un género casi nunca pasado por alto. Por otra parte, se produjeron en el momento en que el retrato fotográfico también cobró

I. Para una discusión global sobre este tema, desde el siglo xv a la contemporaneidad, $c f r$. los ensayos incluidos en Anthony Bond y Joanna Woodall, Selfportrait. Renaissance to Contemporary, Londres, National Portrait Gallery, 2005. Para la construcción de la imagen del artista en el siglo xix, véase Michael Wilson, "Rebels and Martyrs", en Rebels and Martyrs. The Image of the Artist in the Nineteenth Century, Londres, National Gallery, 2006. 
un impulso fundamental a partir de su circulación, primero en las cartes de visite y luego a través de su reproducción incesante en la prensa ilustrada.

Nuestra propuesta para este artículo es poner en relación fotografías, en las cuales los pintores posaron de modo distintivo eligiendo ciertos gestos, vestuarios, atributos o escenarios, con autorretratos pintados, en los que además optaron por determinados recursos plásticos (punto de vista, iluminación, tonos, pincelada), dispositivos que, si bien no son unívocamente legibles, también contribuyeron a tornar visible su estatus como creadores, ya fuese éste adquirido o ideal. Nos interesa examinar las estrategias puestas en juego por cada sujeto a la hora de autorrepresentarse, tanto en los retratos pintados por ellos mismos como en las fotografías tomadas por otros, ya que aquí también se pone en acto un complejo proceso de selección, con un grado importante de conciencia, desplegado por el retratado para exhibirse ante el público de cierta manera. ${ }^{2}$ Es decir, siguiendo el trabajo de Harry Berger, buscamos arrojar luz sobre el acto performático que se produce en el momento de posar (ya sea para otro o para uno mismo), ${ }^{3}$ una actividad implicada en la práctica del retrato en general y que en este caso conduce a la búsqueda de construir imágenes ejemplificadoras de los discursos dominantes sobre qué era o debía ser un artista. El filósofo Jean-Luc Nancy propone que el retrato es el sitio distintivo donde se juega el ser del sujeto representado. Si el retrato permite el "develamiento de un yo", ¿qué sucede en aquellos retratos de sujetos que además son artistas? Podemos pensar entonces estas obras como responsables de revelar, al volverlo visible, el ser del artista. ${ }^{4}$

Analizaremos cómo cuatro artistas argentinos de estéticas diferentes se autorrepresentaron a principios del siglo xx, examinando los autorretratos y los retratos pictóricos y fotográficos realizados por otros y relacionándolos con el lento proceso de profesionalización de la esfera del arte al que asistió Argentina durante ese periodo. Asimismo, nos interesa pensar en qué medida esta lucha por la profesionalización influyó en las imágenes propias o ajenas. Sin embargo, no se trató de un proceso unidireccional en el que primero se obtuvo el estatus que luego se plasmó en las imágenes, sino que estas representaciones se produjeron en paralelo $-\mathrm{y}$ fueron funcionales - al posicionamiento

2. Al respecto, Bond sostiene que "es virtualmente imposible no construir conscientemente nuestra propia imagen"; $c f r$. "Performing the Self", en $o p$. cit., p. 39.

3. Cfr. Harry Berger, Jr., "Fictions of the Pose: Facing the Gaze in Early Modern Portraiture", Representations, núm. 46, primavera de 1994, pp. 87-I20.

4. Jean-Luc Nancy, La mirada del retrato, Buenos Aires, Amorrortu, 2006, p. I6. 
de cada creador dentro de una esfera artística que tendía a formalizarse. $\mathrm{O}$, para decirlo en términos de Nancy, los retratos y los autorretratos fueron "ejecuciones del sujeto/artista". Para este autor, en el retrato se produce el develamiento del ser fuera de sí, es decir, cuestionando las nociones tradicionales de sujeto (aquél aislado de toda alteridad y en relación sólo con sí mismo), por el contrario, lo que emerge en el retrato es la presentación de un mundo, el mundo como arte. 5 La relación del sujeto consigo mismo es, para el filósofo, menos íntima y transparente de lo que se hubiera querido y el sujeto sólo adquiere una identidad frente a otro. ${ }^{6}$ Esta idea resulta productiva para pensar que es en el dominio público donde se construye y fija la idea del artista como ser social.

La consideración de estos casos paradigmáticos permite conocer - a partir del examen de autorretratos, retratos y fotografías puestos en diálogo con la crítica contemporánea - cómo cuatro actores centrales en el arte argentino, que van desde la "aristocracia" de los artistas del siglo XIX hasta los vanguardistas del siglo $\mathrm{xx}$, concibieron su práctica y se presentaron en sociedad. Es decir, el estudio de las estrategias plásticas puestas en juego en cada caso funciona como una vía de acceso para acercarnos a los modos de "ser artista" del maestro decimonónico (Sívori), de aquellos que tuvieron gran éxito de mercado gracias a una pintura de temáticas y lenguajes residuales (Fader y Quirós) y de quien, participando en el movimiento futurista europeo, bregó por la introducción en Argentina de los lenguajes más renovadores del momento (Pettoruti).

En la importante bibliografía producida sobre los cuatro artistas, es poco lo que se ha dicho sobre los autorretratos, y en ningún caso éstos han sido analizados en paralelo con las fotografías contemporáneas, así como tampoco se ha buscado comparar o contraponer los modos elegidos por diversos artistas para representarse. En este punto, nuestra propuesta es trabajar sobre imágenes muy conocidas -e infaltables en cualquier trabajo monográfico sobre estos pintores-, pero escasamente analizadas en su singularidad y mucho menos en sus interrelaciones.

5. Para una lectura del texto de Nancy, $c f r$. la reseña de Noelia Billi en Instantes y azares: escrituras nietzscheanas, núms. 4-5, 2007, pp. 244-249.

6. Nancy adscribe a la doble dimensión de la representación (reflexiva y transitiva) tal como ésta fue postulada por Louis Marin, al sostener que en el retrato se produce la "presencia en sí" y la "puesta fuera de sí" del sujeto. 


\section{Un retrato grupal y un marco de situación}

Diez hombres impecables posan frente a la cámara (fig. I). Unos sentados, otros de pie, todos lucen sus trajes más elegantes: zapatos lustrosos, cuellos duros y pajaritas. Sostienen en las manos los sombreros que se acaban de quitar: bombines e incluso galeras. Todos tienen bigote y varios ostentan un atributo infaltable en un caballero de finales del siglo xix: el bastón. Sólo uno de ellos parece levemente más desaliñado que los demás. Tiene el pelo blanco y largo y una barba hirsuta que le tapa el moño. Es flaco y algo desgarbado, pero está vestido con gran esmero. Es el pintor Eduardo Sívori, el más viejo de todos ellos — aunque lo separen menos de Io años de varios de los demás-; su figura se parece a la de un patriarca. A su lado, sus pares, los otros protagonistas de la escena artística de Buenos Aires, permanecen serios en su papel de miembros del jurado del concurso de becas de estudio a Europa celebrado en I899. Ellos son los pintores Eduardo Schiaffino (primer director del Museo Nacional de Bellas Artes), Reinaldo Giudici, Augusto Ballerini y Fernando Fusoni; los músicos y compositores Julián Aguirre y Amílcar Zanella, y los escultores Lucio Correa Morales, Américo Bonetti y Víctor de Pol.

Era evidente que estos hombres se sentían parte de una elite. Pertenecían a aquel grupo selecto que se dedicaba entonces a la práctica de las bellas artes y que había asumido como propia la cruzada de crear un ambiente artístico en el país. En la fotografía aparecen retratados como un grupo de gentlemen, estatus frecuentemente asociado a la actividad literaria y que aquí se hace extensivo a los pintores y los escultores. De modo explícito, han evitado aparecer sucios o con ropas de trabajo, distanciándose de aquella faceta no intelectual de la práctica artística. El cultivo de las bellas artes era una ocupación de pocos. La pintura de caballete no resultaba una actividad lucrativa en el Buenos Aires del siglo xix, y entonces se debía contar con algún capital previo, propio o heredado, para poder dedicarse a esta práctica. Si bien estos hombres no pertenecían a la oligarquía más tradicional, sí eran hijos de familias acomodadas, muchas de ellas inmigrantes. Esto los habilitó para dedicar toda su vida al ejercicio del arte, aunque en la mayoría de los casos desempeñaron también la docencia, como Sívori, Giudici y Ballerini; la crítica artística como Fusoni, y la gestión cultural en combinación con las otras actividades, como Schiaffino. A casi todos ellos les costó insertar su producción en el mercado. Vendían eventualmente algún paisaje o retrato, pero esto no significaba que contasen con una clientela estable capaz de absorber el flujo de obras al ritmo de su salida del taller. 


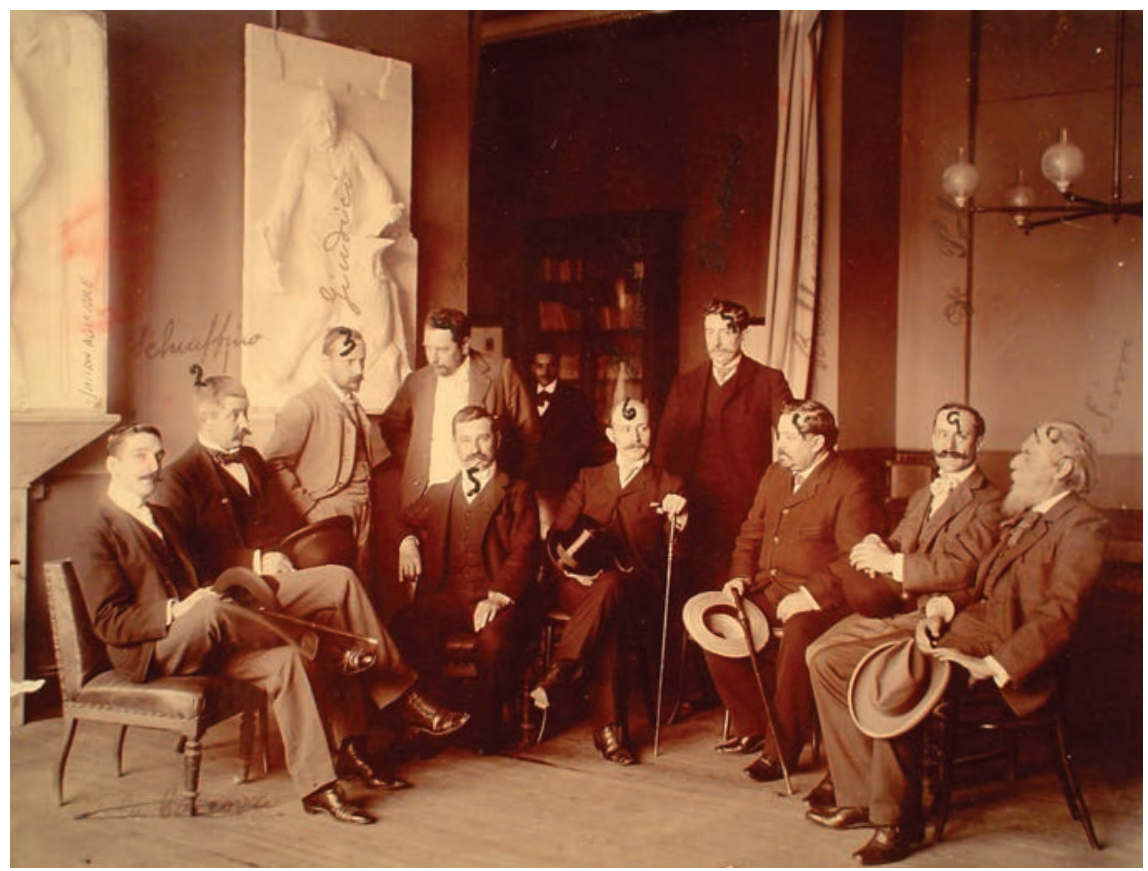

I. Miembros del jurado del concurso de becas de estudio a Europa, I899. Buenos Aires, Archivo General de la Nación, Departamento de Documentos Fotográficos.

La formación de un mercado receptivo al arte argentino fue un proceso que se dio de modo lento y gradual. En el último cuarto del siglo XIX se gestaron las agrupaciones de artistas $^{7}$ y se abrieron improvisados e inespecíficos espacios de exhibición, pero el mercado como tal apenas comenzó a formalizarse en las primeras décadas del siglo siguiente. Sin embargo, no fue un recorrido siempre progresivo. Por el contrario, fue un proceso que podríamos caracterizar de pendular, plagado de retrocesos, en el que era moneda corriente oír las quejas de los artistas ante la escasez de compradores deseosos de adquirir sus producciones.

En I897 se inauguró la primera galería con visos de profesionalidad de la ciudad de Buenos Aires - la antigua casa de fotografía Witcomb, enton-

7. La primera de ellas, la Sociedad Estímulo de Bellas Artes, se fundó en i876. Para una reconstrucción del perfil de esta institución y su lucha por profesionalizar la actividad de los artistas, cfr. Laura Malosetti Costa, Los primeros modernos. Arte y sociedad en Buenos Aires a fines del siglo XIX, Buenos Aires, Fondo de Cultura Económica, 200I, cap. III. 
ces transformada en salón de arte- $\mathrm{y}$ allí comenzaron a celebrarse con cierta recurrencia las exposiciones de artistas locales. ${ }^{8}$ No obstante, esto no implicó que todo lo que se exhibía allí fuese vendido. Si varias de estas muestras alcanzaron el éxito, muchas otras no lo lograron y el remanente de obras que quedaba sin adquirir se iba incorporando en exposiciones posteriores.

Nuevos espacios de exhibición y venta hicieron su aparición en la segunda y en la tercera décadas del siglo xx. En medio de este proceso, un hecho fue capital para la carrera de la mayoría de los creadores de entonces. El Salón Nacional se inauguró en I9II y a partir de ese año todos los meses de septiembre y octubre los artistas contaron con un sitio que les permitía —además de exhibir sus producciones y aspirar a alguna premiación - figurar en el catálogo con un precio de venta que ponía su obra en circulación. ${ }^{9}$ Se instauraba así la estación artística, el momento de mayor condensación de exposiciones y aquel en que los pintores y los escultores esperaban concretar sus mejores ventas.

Poco a poco, los salones se reprodujeron en los centros provinciales y municipales del país y sus respectivas burguesías comenzaron también a mostrarse interesadas por el consumo del arte nacional.

Era una dura batalla, pues el primer coleccionismo de arte que se inició en Argentina en las últimas décadas del siglo xix había expresado un claro favoritismo por la adquisición de arte europeo, mientras que el producido por los artistas del país todavía no entraba en la agenda de compras de los sectores privados. Para estos hombres ilustrados, pioneros en la adquisición artística, el arte nacional aún no era válido para ser coleccionado, aunque sí algo que debía estimularse, ya que — para usar una metáfora común en la épocatodavía estaba "en su infancia". ${ }^{\circ}$

En medio de todo este panorama, quienes practicaban la pintura y la escultura se irían adscribiendo a distintos modos de ser artista. Entre los afi-

8. Sobre su historia, $c f r$. Marcelo Pacheco, Memorias de una galería de arte: archivo Witcomb 1896-1971, Buenos Aires, Fondo Nacional de las Artes, 2000.

9. Acerca de la creación del Salón Nacional, véase el trabajo señero compilado por Marta Penhos y Diana B. Wechsler, Tras los pasos de la norma. Salones Nacionales de Bellas Artes (I9I I1989), Buenos Aires, Jilguero/Archivos del CaIa 2, I999. Sobre el Salón y el mercado, $c f r$. nuestro texto "Una historia de soslayos: la génesis de un mercado para el arte argentino", en Imágenes perdidas. Censura, olvido, descuido, IV Congreso Internacional de Teoría e Historia del Arte/XII Jornadas CAIA, Buenos Aires, Centro Argentino de Investigadores de Arte, 2007, pp. 33 I-344.

Io. La formación del primer coleccionismo ha sido el objeto de mi tesis doctoral, publicada bajo el título Los dueños del arte. Coleccionismo y consumo cultural en Buenos Aires, Buenos Aires, Edhasa, 2006. 
cionados empezó a delinearse la figura del artista profesional. ${ }^{\text {II }}$ Con esto no queremos decir que en las primeras décadas del siglo xx ya existiese un grupo numeroso de pintores y escultores que viviese exclusivamente de su producción artística. Si estudiar en la academia y dedicarse a la pintura o a la escultura podían ser pensadas como carreras posibles, incluso como medios de ascenso social, nada garantizaba el éxito y la docencia: las artes decorativas y la ilustración continuaban funcionando como ocupaciones complementarias. Fueron pocos los que hacia este momento pudieron dedicarse de tiempo completo al ejercicio del arte. Sin embargo, las trayectorias personales y los consecuentes modos de ser artista comenzaron a distinguirse lentamente de aquellos que caracterizaron a la elite de artistas decimonónicos, a los que Laura Malosetti Costa definió como "los primeros modernos" "I2 y que tan certeramente retrata la foto con la cual abrimos este apartado.

Este nuevo estatus, si no enteramente logrado, al menos en vías de ser alcanzado, influyó de diverso modo en los autorretratos que signaron casi todas las carreras artísticas emprendidas durante las primeras décadas del siglo. Éstos fueron en general arenas de experimentación, muchas veces realizados en la intimidad del taller y concebidos exclusivamente para la esfera doméstica, y en otros casos pensados como cartas de presentación que pretendían ser vistas y eventualmente adquiridas entre el público que se interesaba por el arte local.

\section{Sivori}

En caricaturas, pinturas y fotografías, los rasgos particulares de Eduardo Sívori (I847-I9I8) (fig. 2) fueron acentuados al punto de volverlos su marca distintiva. Largo cabello blanco peinado hacia atrás, acompañados por la frente cada vez más amplia tras el paso de los años, barba y bigote también largos y blancos y pequeños anteojos redondos encajados en las profundas cuencas de los ojos. En su cabello y en su barba algo indómitos y en un atuendo en el que era habitual encontrar detalles vistosos, como el gorro turco, el "más

II. Véase el primer acercamiento a esta problemática a partir de las fotografías que circularon en la prensa entre finales del siglo XIX y principios del xx en nuestro artículo "La imagen del artista. La construcción del artista profesional a través de la prensa ilustrada", en Laura Malosetti Costa y Marcela Gené (comps.), Impresiones porteñas. Palabra e imagen en la historia cultural de Buenos Aires, Buenos Aires, Edhasa, 2009, pp. 47-80.

I2. Malosetti, op. cit. 


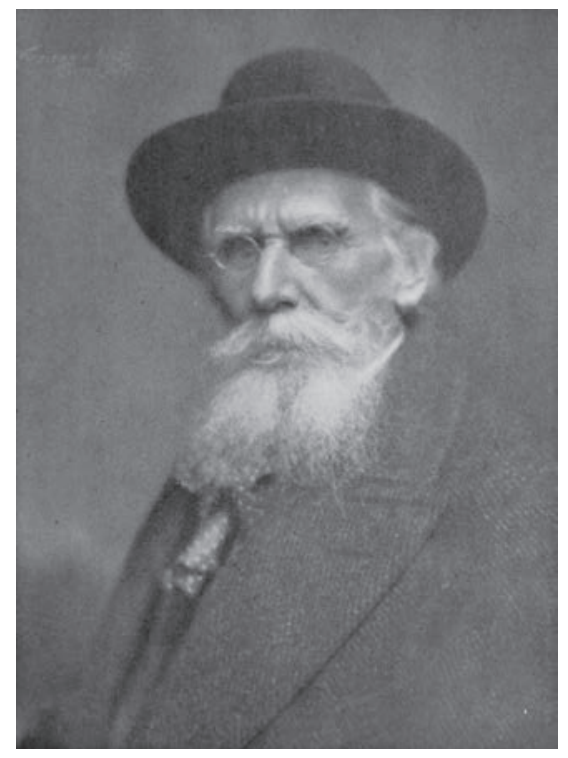

2. "Sívori", Páginas Gráficas, núm. I7, suplemento, septiembre-octubre de I9I5, s.p.

viejo de los jóvenes" forzaba levemente la identidad aportada por la ropa y la postura burguesas para introducir esta versión asociada con la aristocracia y la bohemia que constituía un topos dentro de la vida de los artistas. ${ }^{13}$

Considerado un patriarca de las artes plásticas locales, Sívori fue retratado por alumnos y admiradores, como Mario Canale, uno de sus discípulos dilectos, y Cesáreo Bernaldo de Quirós (I879-I968), artista formado en los últimos ańos del siglo en la Sociedad Estímulo de Bellas Artes que Sívori había contribuido a crear dos décadas antes. Pintado hacia I9ıo, el retrato realizado por este último lo muestra con sus pinceles y su paleta frente a una tela, llevando en la cabeza el distintivo gorro ya mencionado (fig. 3). Allí, en el momento de posar frente a Quirós, Sívori detiene su labor y retrae la mano en la que lleva el pincel para fijar sus ojos penetrantes en el espectador. La vegetación que asoma en la esquina superior izquierda y el cielo texturado del fondo de la escena dan cuenta de que la acción, ahora en suspenso, se desarrollaba al aire libre. Esta ubicación refuerza el lugar de Sívori como el pintor del paisaje nacional de la pampa, el principal género cultivado por el

I3. Para el final del siglo xix en Europa, $c f r$. Amelia Jones, "Clothes Makes the Man: The Male Artist as a Perfomative Function”, Oxford Art Journal, vol. 18, núm. 2, 1995, pp. I8-32. 
3. Cesáreo Bernaldo de Quirós, Retrato

del pintor Sivori, ca. I9го, óleo sobre tela, I $10 \times 99 \mathrm{~cm}$, inv. 6260, Buenos Aires, Museo Nacional de Bellas Artes. Cortesía de Mario Cesáreo Bernaldo de Quirós.

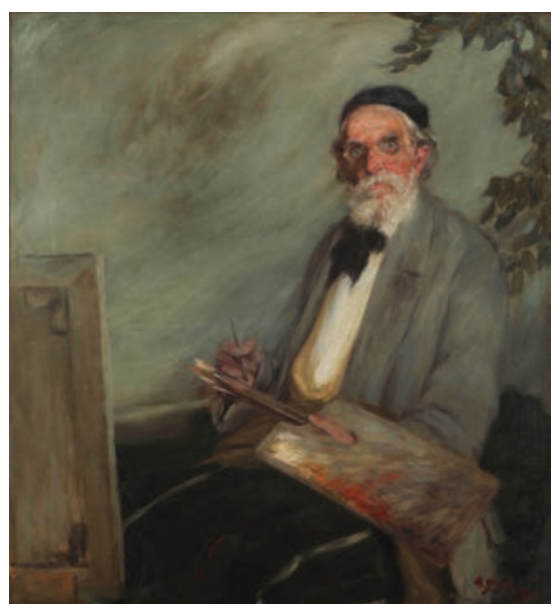

artista a principios del siglo. ${ }^{\mathrm{I} 4} \mathrm{Su}$ mirada es seria, un rasgo característico en la mayoría de los retratos de este periodo, dando por hecho el que ser un artista argentino implicaba la posesión de un temple particular capaz de soportar el largo batallar en pos de la creación de un ambiente favorable para las artes plásticas. Así, puede pensarse que esta necesidad de ennoblecer al representado, sin perder el registro realista, tenía que ver con la exaltación de sus cualidades morales. Esta operación, mediante la cual la idealización fisonómica era el testimonio de las virtudes morales de ciudadanos que debían funcionar como ejemplares, habitual en la tradición retratística decimonónica de héroes y ciudadanos ilustres, ${ }^{15}$ se hacía extensiva aquí a un artista plástico. ${ }^{16}$

I4. Cfr. Marta Penhos, "Eduardo Sívori y el problema de un 'paisaje nacional'”, en Segundas jornadas. Estudios e investigaciones en artes visuales y música, Buenos Aires, Instituto de Teoría e Historia del Arte Julio E. Payró, 1996, pp. I2-I9.

15. Para la construcción de la figura del héroe en la Argentina del siglo xix, son centrales los trabajos de María Lía Munilla Lacasa, "Siglo XIX: I8Io-I870", en José Emilio Burucúa (dir.), Nueva historia argentina. Arte, sociedad y politica, Buenos Aires, Sudamericana, I999, y Roberto Amigo, "Imágenes de la historia y discurso político en el estado de Buenos Aires (I852-I862)", en Roberto Amigo y Patricia Dosio, Arte argentino de los siglos XVIII y/o XIX, Buenos Aires, Fundación Espigas-Fondo para la Investigación del Arte Argentino, I999.

I6. El retrato fotográfico de estudio también aspiró a aprehender algo de la "comprensión moral" del sujeto representado. En este sentido, a mediados del siglo xix Nadar se refería al "entendimiento instantáneo que te pone en contacto con el modelo, te ayuda a resumirlo, te guía así sus hábitos, sus ideas y su carácter" que permitía la captación de un "retrato íntimo". 


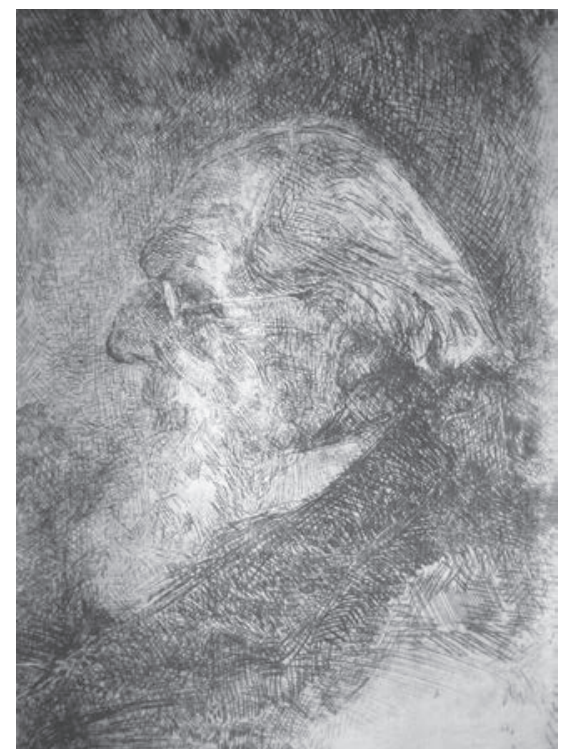

4. Mario A. Canale, Eduardo Sivori, ca. I9I2, aguafuerte, $25.5 \times 16 \mathrm{~cm}$, Buenos Aires, Fundación Espigas. Cortesía de Haydée Demaría de Canale.

Por su parte, Mario A. Canale (I890-I95I) realizó hacia I9I 2 varias versiones, en grabado sobre metal, del perfil de su maestro (fig. 4). Sívori no sólo había sido responsable de introducir a Canale en esta técnica, sino que junto a Emilio Agrelo fue uno de los precursores en investigar las posibilidades del aguafuerte en el medio local. No era casual entonces que Canale eligiese este medio para homenajearlo.

En los estudios sobre el retrato de principios de la época moderna, la vista de perfil generalmente se ha asociado con un mayor proceso de abstracción del rostro y una menor adecuación a volver evidente su estructura física. El alejamiento que propone el perfil, estilísticamente cercano al relieve funerario, expresa el deseo de trascender la imagen "natural" del ser para acercarse a la idealidad de un icono. ${ }^{17} \mathrm{Si}$ ya este proceso de abstracción se trasuntaba en el aguafuerte de Canale, mucho más patente es la operación puesta en juego por el propio Sívori en un autorretrato realizado hacia i9I5 (fig. 5), el de mayor interés de los considerados hasta aquí, sobre todo si lo comparamos

Citado por John Tagg, El peso de la representación. Ensayos sobre fotografías e historias, Barcelona, Gustavo Gili, 2005 , p. 72.

I7. Véase Berger, Jr., op. cit., pp. I05-Io6. 
5. Eduardo Sívori, Autorretrato, ca. I915, óleo sobre tela, $55 \times 42 \mathrm{~cm}$, Rosario, Museo Municipal de Bellas Artes Juan B. Castagnino + macro.

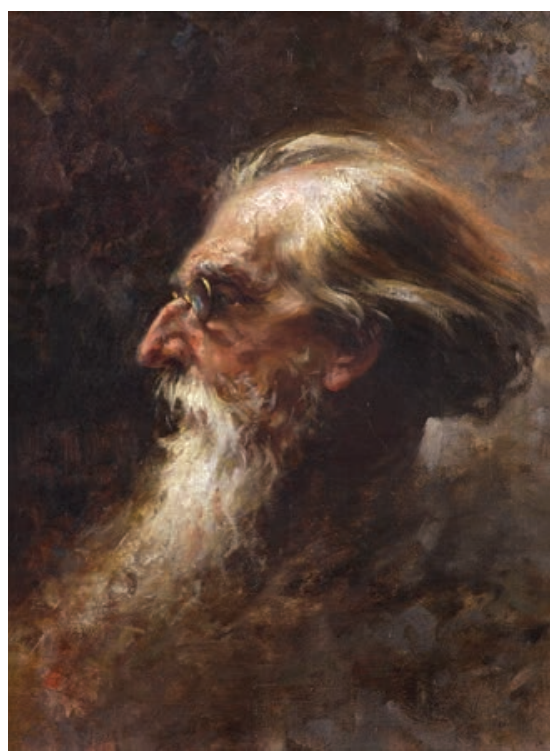

con el más tradicional, realizado en I900, en el que el artista gira la cabeza para, con un gesto amable, dirigir la mirada hacia el observador. ${ }^{18}$

En la obra ejecutada hacia el final de su vida (Sívori muere en I9I8), si bien el rostro se volvió más anguloso, se repiten el cabello peinado hacia atrás, la barba blanca y los pequeños anteojos. La pincelada es muy suelta y se hace evidente la huella del pincel en varios lugares de la pintura. Lo más curioso es el modo en que la cabeza flota sobre el fondo neutro, al punto de no parecer corresponderse con un cuerpo real. El rostro se transforma en efigie, a la manera de los perfiles de los próceres que encontramos en las monedas. El juego del claroscuro impresiona y otorga gran dramatismo al cuadro. Tanto en su concepción como en su ejecución, es un retrato muy moderno para los parámetros del pintor y de la pintura que entonces circulaba por Argentina. Es un retrato abstracto que no aporta referencias espaciales y tampoco incorpora ningún atributo concreto del hacer del artista más que la propia pictoricidad implícita en la pincelada enfática, que sobresale mucho más que en obras tempranas del pintor. Quizá se respire aquí algo de aquello que Edward Said señaló respecto

I8. Eduardo Sívori, Autorretrato, I900, óleo sobre tela, $58 \times 46 \mathrm{~cm}$, inv. I663, Museo Nacional de Bellas Artes (MNBA). 


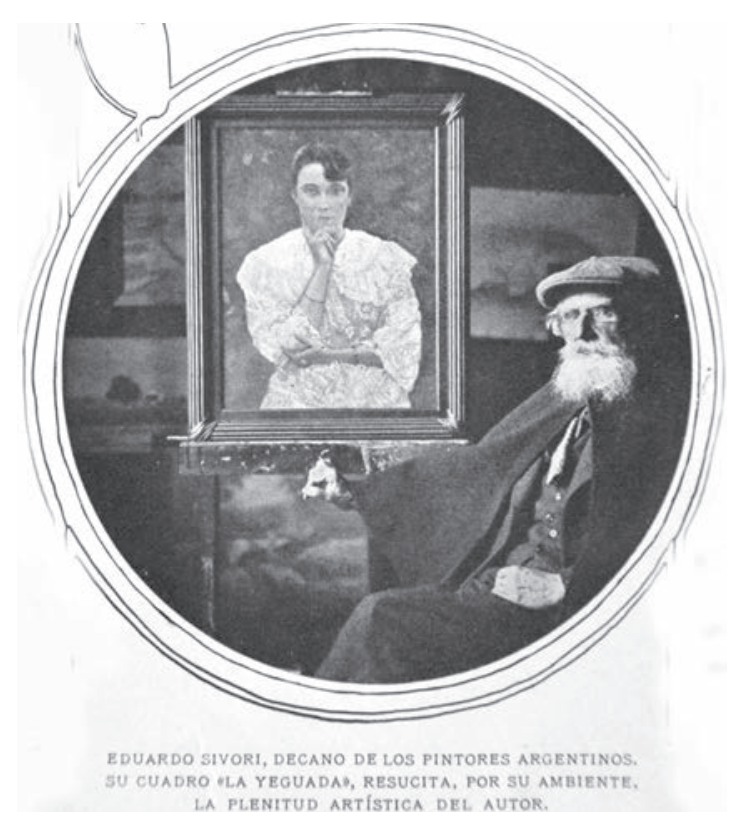

6. "Eduardo Sívori, decano de los pintores argentinos", Plus Ultra, año 2, núm. I7, septiembre de I9I7, s.p.

de la producción tardía de los artistas considerada no como un momento de armonía y resolución sino de intransigencia, dificultad y contradicciones no resueltas que transmiten un sentimiento trágico. ${ }^{19}$ Así quiso retratarse Sívori hacia el final de sus años: convirtiendo su rostro en el emblema del artista a partir de recursos propios del hacer de la pintura.

Esta solución moderna, por otra parte, contrasta con el modo en que el artista fue fotografiado por esta misma época. Sívori siguió enviando obras al Salón Anual hasta poco antes de su muerte. Si comparamos su fotografía, que la suntuosa publicación Plus Ultra incluyó en ocasión de la crónica del Salón de 1917, con la del resto de los artistas, ésta lo muestra como el más anticuado, pero también el más excéntrico de los retratados (fig. 6). ${ }^{20}$ Con su

19. Edward Said, Sobre el estilo tardio. Música y literatura a contracorriente, Buenos Aires, Debate, 2009, pp. 29 y 33.

20. Antonio Pérez Valiente, "VII Salón Anual de Arte. Algunos expositores y sus obras", Plus Ultra, Buenos Aires, año 2, núm. I7, septiembre de I9I7. 


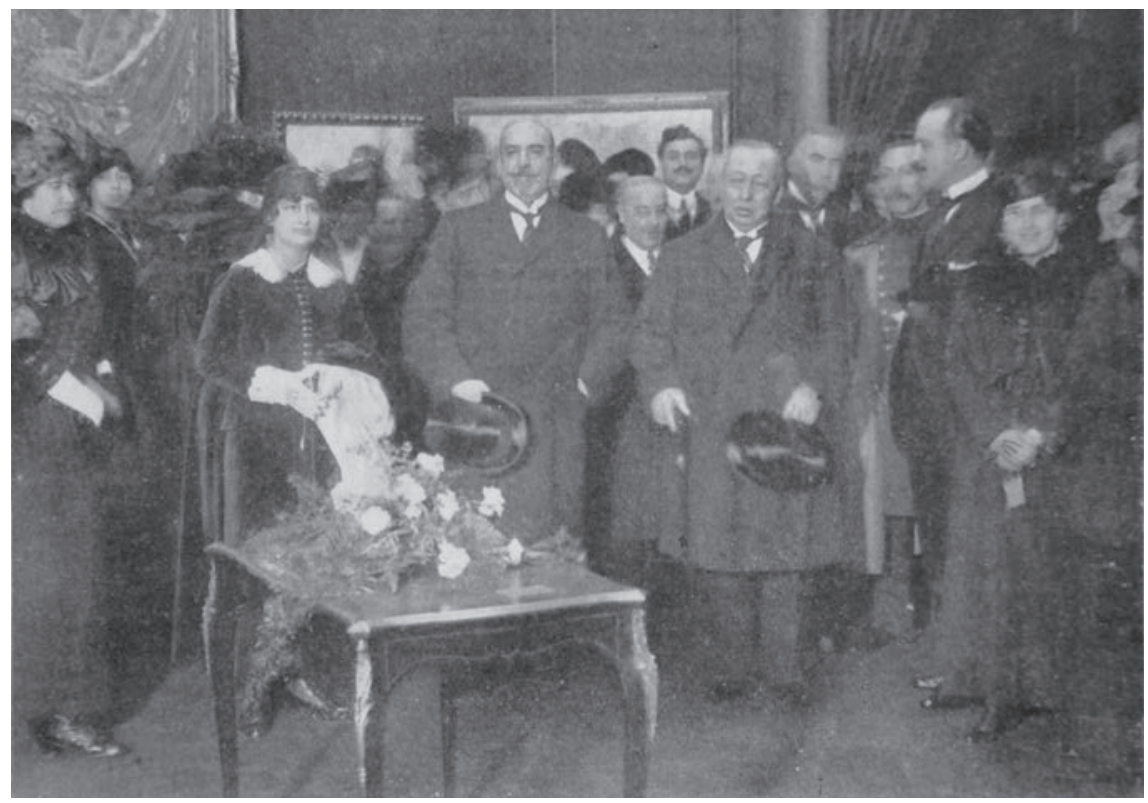

7. “Exposición Quirós”, Myriam, año I, núm. 2, julio de I9I5, p. I3.

extensa barba blanca, su boina y el gesto majestuoso con que posa una mano sobre el cuadro, que habilita el despliegue de su capa, Sívori encarnaba claramente los modos decimonónicos de ser artista. No vestía las ropas de moda ni el equipo de trabajo que portaban los más jóvenes, sino que seguía representando a aquella aristocracia del espíritu a la que pertenecía como buen "decano de los pintores argentinos", tal como señalaba el epígrafe de la fotografía.

\section{Quirós}

Muy distinto era el mecanismo con que Césareo Bernaldo de Quirós, recién retornado de Europa a causa de la guerra, aparecía retratado en ocasión de su exposición celebrada en I9Is en los salones de la Comisión Nacional de Bellas Artes. En vez de los habituales retratos en solitario, la lujosa revista Myriam incluyó una fotografía "de actualidad" tomada el día del vernissage (fig. 7). Las nuevas posibilidades técnicas del proceso fotográfico que facilitaban la 
realización de tomas fuera del estudio al reducir los tiempos de exposición daban como resultado retratos menos posados y más asociados a la captura de un momento fugaz.

Aquí, en el centro de la escena, el presidente de la nación, Victorino de la Plaza, con bastón y galera en mano, está rodeado por su comitiva y por Quirós, quien lo mira desde un lateral. Esta inédita y estrecha vinculación entre artistas y poder ejecutivo ya se había producido en exposiciones anteriores de Quirós y de otros miembros del grupo Nexus, cuyas inauguraciones eran frecuentadas por el entonces primer mandatario José Figueroa Alcorta. ${ }^{2 \mathrm{I}} \mathrm{Sin}$ embargo, la visita presidencial a una exposición de pintura, anunciada semanas antes por la prensa, seguía siendo un acontecimiento excepcional a los fines de la promoción del artista. Era vital preservar el suceso a través de una fotografía e incluso acceder a desplazar hacia el margen al creador para ceder el sitio privilegiado al gobernante.

Más tradicional fue el modo en que Cesáreo apareció fotografiado en Plus Ultra tres años después (fig. 8). La crónica comenzaba describiendo el lujo que caracterizaba el ambiente y los objetos que rodeaban al artista. ${ }^{22}$ Todo trasuntaba la alta reputación lograda por el pintor gracias a la venta de paisajes y sus tipos gauchescos. Con un último resabio de juventud en el rostro, con aplomo, seguro de sí mismo, así lo muestra el retrato que corona el artículo. La elegancia de su traje impresiona. La camisa perfecta deja adivinar los gemelos y las manos, excesivamente cuidadas, se juntan en un ademán refinado, realzado por un gran anillo. Es, sin duda, el prototipo del artista burgués que practicaba una vida lujosa y opulenta y gustaba de vestir con esmero. Nada había en su apariencia que permitiera alejarlo de los códigos dominantes asociados con la vestimenta masculina de clase acomodada, como quizá sí podía observarse en alguna de las - leves- excentricidades que encontramos en Sívori. La modelo desnuda que posa frente a él, en la foto que acompaña su retrato individual, refuerza la subjetividad masculina expresada por la ropa. El genio artístico era corporizado por el hombre, así como el desnudo feme-

2I. Formado en Roma a comienzos del siglo, Nexus estaba integrado —además de Quirós- por los pintores Pío Collivadino, Alberto M. Rossi, Justo Lynch, Carlos Ripamonte y Fernando Fader y los escultores Arturo Dresco y Rogelio Yrurtia. Este grupo realizó tres exposiciones en Buenos Aires en 1907 y 1908, las cuales no obtuvieron las ventas esperadas. Cfr. Laura Malosetti Costa, Collivadino, Buenos Aires, El Ateneo, 2006, pp. 69-85.

22. Víctor Andrés, "Nuestros pintores. Cesáreo Bernaldo de Quirós", Plus Ultra, Buenos Aires, año 3, núm. 27, julio de I918. 
DOI: http://dx.doi.org/10.22201/iie.18703062e.2012.100.2330

REPRESENTACIÓN Y AUTORREPRESENTACIÓN EN EL ARTE
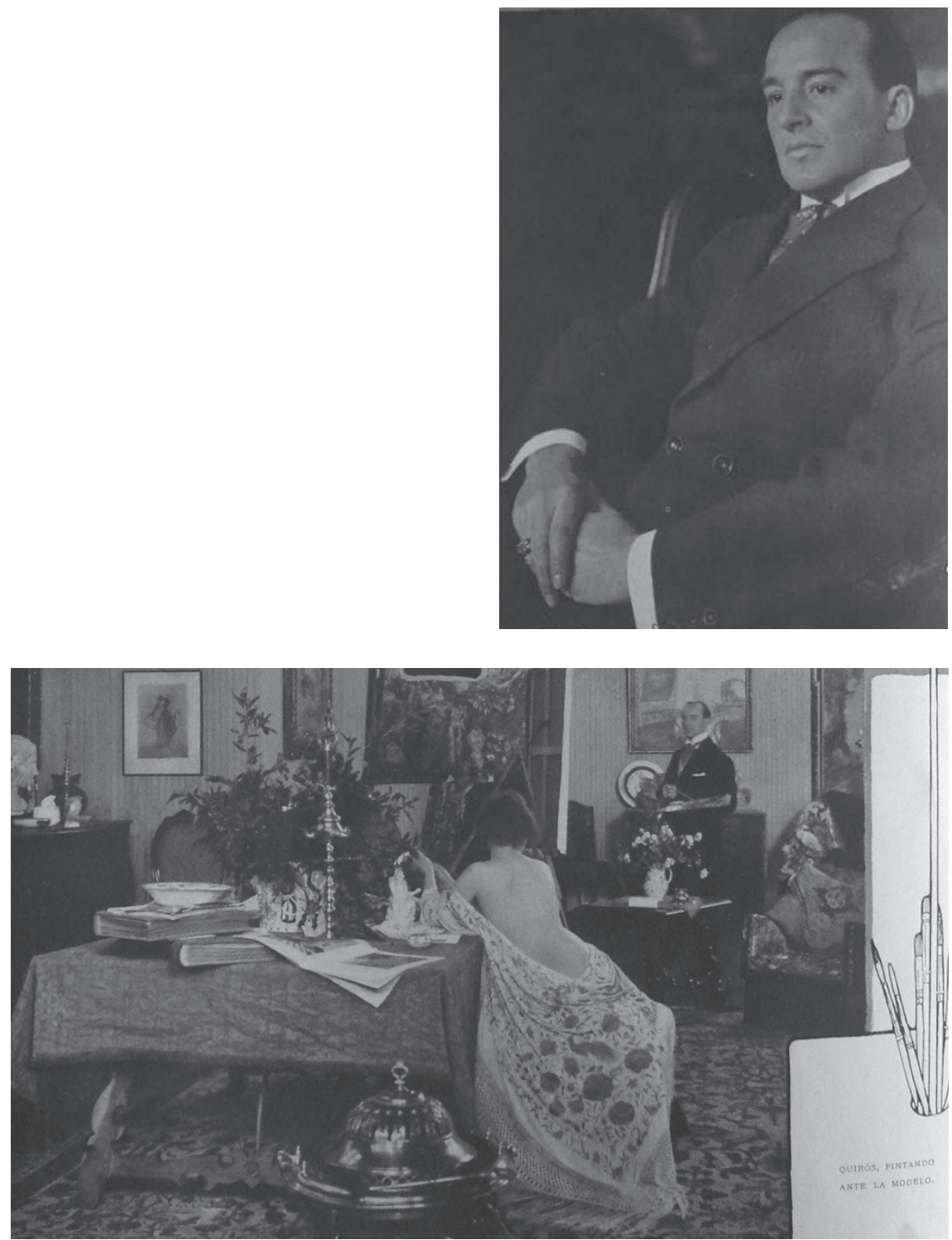

8. "Nuestros pintores. Cesáreo Bernaldo de Quirós", Plus Ultra, año 3, núm. 27, julio de I9I8, s.p. 
nino reafirmaba la mirada deseante también enmarcada en cánones androcéntricos. ${ }^{23}$ De hecho, Io años más tarde esta oposición configuradora entre el macho-artista y la hembra-modelo que vislumbramos en la fotografía de Plus Ultra se hacía explícita en una crónica del diario La Nación que, partiendo de la descripción física del artista, reafirmaba esta dualidad:

CESÁReo le pusieron y su garra es de césar [...] Hacía tiempo que deseaba estrechar su mano. Aunque ya le suponía también lleno de vigor físico para poder soportar tan púgil batalla, no le creía tanto, sin embargo. Y me hallé con un hombre alto, con un pecho amplio, de puño macizo, de andar ágil y musculoso. Sus ojos pequeños y acerados, ardían con un fulgor de fiebre. Sonreía con franqueza, mostrando sus dientes de mujer. [...] Quirós, que es un gran pintor de naturaleza viva, compone en la tibia atmósfera de la alcoba algún desnudo sonrosado de mujer-gata, de carne mórbida y palpitante. [...] Una hembra con ojos de antílope y cutis de perla. ${ }^{24}$

Estas características de masculinidad, connotadas tan claramente por su figura, eran extensivas a su producción caracterizada como "pintura de varón, fuertemente sexuada", al decir de José León Pagano, quien fue uno de sus sostenedores intelectuales más duraderos a lo largo del tiempo. ${ }^{25}$

¿Por qué la identidad burguesa cuadraba tan bien a Quirós con su modo de ser artista? Es necesario aclarar que el entrerriano fue uno de los primeros argentinos que lograron insertar ventajosamente su producción en términos comerciales. Fue el artista vernáculo más favorecido económicamente en la Exposición Internacional de Arte del Centenario celebrada en igio y en los años subsiguientes su carrera no hizo más que afirmarse de la mano de los éxitos en los salones y en las exposiciones de Argentina, Uruguay y Chile. Recibió los elogios de la prensa, que en 1916 celebraba, por ejemplo, el encargo de decorar algunas salas del Jockey Club de Rosario por el que recibiría la impresionante suma de 50000 pesos. ${ }^{26}$

23. Cfr. Rozsika Parker y Griselda Pollock, "God's Little Artist", en Old Mistresses. Woman, Art and Ideology, Londres, Pandora Press, 1992 [primera ed., 198I].

24. Ernesto Mario Barreda, "Bernaldo de Quirós", La Nación, Buenos Aires, I6 de octubre de 1927 , p. II.

25. Cfr. su texto en Quirós. Discursos y conferencias pronunciados con motivo de la exposiciónhomenaje de la obra del pintor, Buenos Aires, Peuser, I948, p. 7.

26. "La decoración del Jockey Club de Rosario", La Nación, Buenos Aires, 2 I de diciembre de 1916, p. I3. 
9. Cesáreo Bernaldo de Quirós, Autorretrato, s.f., óleo sobre tela, $\mathrm{I} 22 \times 66 \mathrm{~cm}$, Buenos Aires. Colección Fortabat. Cortesía de Mario Cesáreo Bernaldo de Quirós.

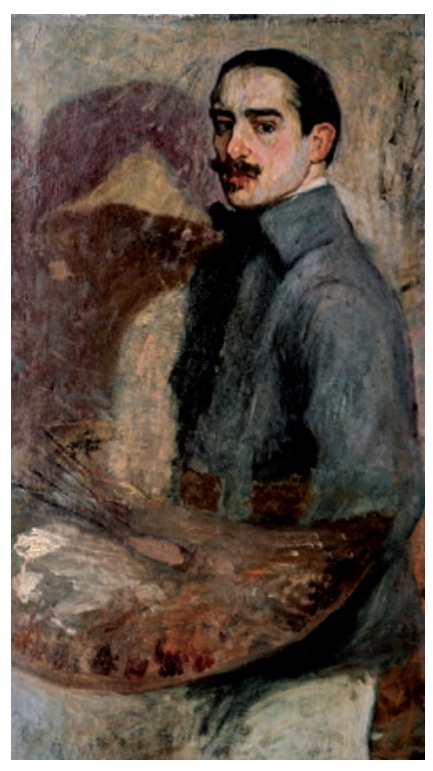

Posición económica y carrera artística se volvían un mismo objetivo para Quirós, al punto de no poder disociar una de otra. Ya en sus fotos de juventud, tomadas en ocasión del concurso de becas a Europa, un Quirós de apenas 20 años se caracterizaba por su gran cuidado y elegancia al vestir y la habilidad para desplegar estos atributos a la hora de ser fotografiado, como si éstos fueran necesarios e intrínsecos a su condición de artista. Quizá mucho tenía que ver el ser descendiente de una familia de noble estirpe española que, si bien había afrontado diversas vicisitudes domésticas y económicas, lo ubicaba sin duda en lo más granado de la elite de su provincia natal. ${ }^{27} \mathrm{Su}$ garbo y su silueta arrogante hicieron que, una vez arribado a Florencia, se le conociera con el nombre de "il bel pittore". ${ }^{28}$

El autorretrato sin fecha, pero que seguramente concretó hacia la segunda década del siglo, lo muestra en el momento mismo de realización de una pintura (fig. 9). Con una inmensa paleta en la mano, arma infaltable que denota el

27. Era hijo de un letrado español, radicado en la provincia argentina de Entre Ríos a mediados del siglo XIX, y de una criolla de ascendencia portuguesa de origen humilde. Sus ańos de juventud estuvieron signados por problemas sanitarios y domésticos, entre otros la pérdida del trabajo de su padre y la temprana muerte de su madre en I895. Cfr. Graciela Kartofel, Quirós, Buenos Aires, Centro Editor de América Latina (Pintores Argentinos del Siglo Xx, 5), 1980, pp. I-2.

28. Emilio Pettoruti, Un pintor ante el espejo, Buenos Aires, Hachette, I968, p. 37. 
oficio, y la mirada clavada en el espectador, hay algo en la obra que recuerda a una instantánea como si el artista hubiera interrumpido su labor por un segundo para volverse ante el objetivo de una cámara. Es un retrato más tradicional y explícito que el realizado tardíamente por Sívori, en primer lugar porque aquí se establece un vínculo con el espectador, pero también porque el artista aparece ligado sensorialmente con los elementos y la tela que está pintando. En su factura priman los recursos plásticos que entonces eran usuales en el resto de su producción: pincelada evidente, empastada y paleta clara; sin embargo, el único sitio que aparece con detalle es su rostro. El resto de la pintura está resuelto con manchas más abocetadas, culminando en una fusión de artista y fondo que transforman en un ser único al cuadro y a aquel que lo realiza.

La mirada del artista también es el elemento predominante en un autorretrato posterior, de gran tamaño, hoy en poder del Museo Provincial de Bellas Artes Rosa Galisteo de Rodríguez de Santa Fe (fig. Io). Éste fue realizado durante la estadía del pintor en los Estados Unidos en 1934, cuando vivía en la casa de su amiga Ruth Leonard en la ciudad de Westport. La carrera del pintor se encontraba altamente cimentada para estos años. Su serie de Los gauchos, enormes cuadros costumbristas que evocaban a los protagonistas de la guerra civil ocurrida en su provincia natal durante el siglo XIX, ${ }^{29}$ había obtenido sonado éxito en Europa para luego descollar en los centros de las costas este y oeste de los Estados Unidos. ${ }^{30}$ Con el impulso del embajador argentino en Washington, Felipe Espil, Quirós se movió con soltura entre la high class y la clase política de aquel país, recibiendo incluso la visita de la esposa del presidente Hoover a la inauguración de su muestra en la National Gallery de Washington.

Algunas de sus obras fueron integradas a la colección Huntington de Nueva York y el artista aprovechó su estancia allí y en territorio canadiense para pintar paisajes y retratos. En el primer autorretrato que realizó en el transcurso de esta "gira triunfal", ${ }^{1}$ la paleta es aún más clara que en la versión juvenil, del mismo modo que se distingue por sus ropas menos formales: chambergo, camisa de franela gruesa a cuadros, tiradores, echarpe al cuello y guantes y la

29. Esta serie fue tempranamente leída en clave nativista por su capacidad de sacar a la luz "el substratum permanente del alma de una raza"; $c f r$. Antonio Dellepiane, "La pintura gauchesca y la obra de Quirós”, Plus Ultra, Buenos Aires, año I I, núm. I I7, 3 I de enero de 1926.

30. Para el detalle de las actividades de Quirós en los Estados Unidos, cfr. Ignacio Gutiérrez Zaldívar, Quirós, Buenos Aires, Zurbarán, I991, pp. 254-263.

31. Cfr. Carlos A. Foglia, Cesáreo B. de Quirós, Buenos Aires, Ediciones Culturales Argentinas, I96I, pp. 34-35. 
Io. Cesáreo Bernaldo de Quirós, El pintor

(autorretrato), 1934, óleo sobre tela,

$132 \times 107 \mathrm{~cm}$, Santa Fe, Museo Provincial de Bellas Artes Rosa Galisteo de Rodríguez.

Cortesía de Mario Cesáreo

Bernaldo de Quirós.

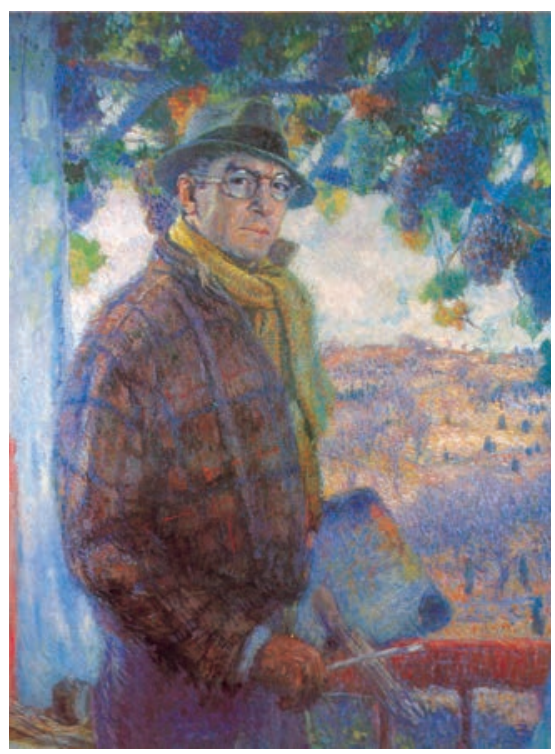

cara afeitada que lo caracterizará hasta el final de su vida. El abrigo provisto por la vestimenta, inadecuado para el transcurrir dentro del taller, alude a la pintura llevada adelante al plein air. De hecho, Quirós se yergue delante de un balcón enmarcado por cortinas vaporosas que dejan ver un paisaje con árboles florecidos y parte de una pérgola con una vid cargada de racimos. La naturaleza no sólo actúa como fondo sino que también remplaza el cuadro ausente evocado por medio del manojo de pinceles y la paleta que el artista ostenta en sus manos. Pintura y naturaleza se vuelven entonces una única cosa, reivindicando una vez más esta inmersión y fidelidad del artista hacia los temas y los paisajes que se vuelven el Leitmotiv repetidamente enunciado por el propio artista: "realizar arte significa para mí, una constante, renovada, convivencia con la naturaleza, a la que llego sumiso y reverente. Internándome en ella, busco el vocablo que en concordancia con mi verdad, mejor pueda expresar lo que la retina observa y el cerebro manda", sostenía dos años después de pintar el autorretrato, en ocasión de la exhibición de ésta y otras pinturas en la galería Amigos del Arte en octubre de $1936 .{ }^{32}$ Más conflictivo e inquietante

32. "Palabras de Cesáreo Bernaldo de Quirós", Plástica, Buenos Aires, núm. Io, octubre de 1936; cfr. también el discurso del artista en Discursos del ministro de Instrucción Pública 
es el otro retrato que pintó en el contexto de este viaje (fig. II), en el que se observa al artista vistiendo sobretodo, chalina y guantes, delante de una ventana en la que se delinean rascacielos y un edificio en construcción. El pintor, levemente más alto que la arquitectura pujante y moderna que le sirve de fondo, se dispone a sacarse el guante para comenzar a pintar. Por delante, en sombras, un criado negro sostiene los pinceles y la paleta con los colores dispuestos en los extremos, preparados con antelación para Quirós. El sirviente, plasmado con rasgos sintéticos y algo grotescos y fríos tonos azules, gira su rostro volviéndolo evidente al espectador y eludiendo así la mirada del pintor. Su presencia funciona como un alter ego: refuerza la posición social del artista - señorial en sus ropas y en su porte- al perpetuar un tópico dominante en la literatura y la pintura decimonónicas que desde una mirada exotista otorgaba al "otro" ese papel subalterno, funcional a la afirmación del sí.

\section{Fader}

Compañero de Quirós en el grupo Nexus, también Fernando Fader (I8821935) fue un caso emblemático entre los artistas que contaron con un mercado receptivo de su obra, sobre todo entre la clientela particular. Como tal, su retrato fotográfico fue una presencia repetida en la prensa contemporánea, que, junto a las reseńas que se encargaban cada ańo de sus exposiciones, contribuyeron a cimentar su fama y su trayectoria. Formado en la Academia de Bellas Artes de Múnich y perteneciente a una familia de empresarios alemanes que llevaba adelante en Argentina emprendimientos hidráulicos de gran escala, este pintor tuvo una mentalidad comercial con la que pudo concebir la producción artística como un medio de subsistencia.

Ya en 1914, el artista en ascenso había rechazado los 3000 pesos que correspondían al primer premio del Salón Nacional al considerar que su obra Las manilas valía el doble. Si bien hay versiones que afirman que el rechazo se debía al embargo de sus bienes por la quiebra de la usina hidroeléctrica de Cacheuta (en la provincia de Mendoza) el año anterior, ${ }^{33}$ lo que más destaca

y Fomento, Dr. Pio Pandolfo y del director del Museo D. Horacio Caillet-Bois. Conferencia del pintor don Cesáreo Bernaldo de Quirós, en el acto inaugural de su exposición en el Museo de Bellas Artes "Rosa Galisteo de Rodríguez" el día 24 de mayo de 1937, Buenos Aires, Ministerio de Instrucción y Fomento, 1937.

33. Para el derrotero de esta obra, $c f r$. la ficha de catálogo razonado de Ana María Telesca 
I I. Cesáreo Bernaldo de Quirós, Autorretrato (el pintor en Nueva York) I934, óleo sobre cartón, I52 × II $5 \mathrm{~cm}$, Paraná, Argentina, Museo Provincial de Bellas Artes Pedro E. Martínez. Cortesía de Mario Cesáreo Bernaldo de Quirós.

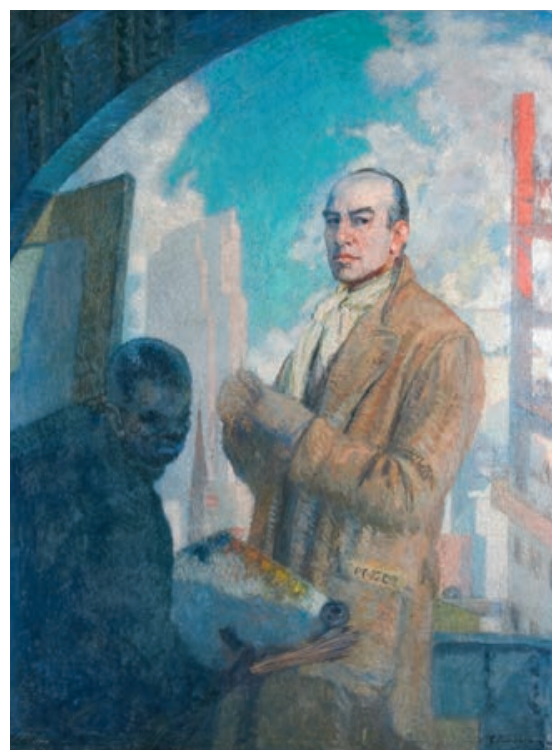

en este gesto es la capacidad de Fader de considerar la carrera de artista como un proyecto redituable, como la única posibilidad de salvación frente al fracaso económico de la empresa familiar.

En este proceso desempeñó un papel central su amigo alemán Federico Müller, quien fue sin duda uno de los ejemplos tempranos de marchand profesional que logró ubicar comercialmente — de modo sostenido en el tiempo- la obra de un artista argentino. El pintor era consciente de la responsabilidad del propio Müller al haberlo ayudado a despegar y ganarse la vida con la pintura:

Mientras estuve en Buenos Aires, he pasado con mi familia días de tristísima miseria [...] Si después he podido abrirme camino nuevamente, fue con ayuda del señor Federico Müller, quien durante más de un año me sostuvo, adelantándome una mensualidad (hasta de quinientos pesos por mes) a fin de poder atender mi salud, y luego después, tomando él a su cargo la venta — previa valoración— de mis telas. ${ }^{34}$

en Museo Nacional de Bellas Artes. Colección, Buenos Aires, Asociación Amigos del mnba, 2010, vol. 2, pp. I28-I29.

34. Apud Antonio Lascano González, Fernando Fader, Buenos Aires, Ediciones Culturales Argentinas, 1982, p. 27. 
El último año en que Fader expuso en el Salón Nacional fue i9is para luego hacerlo en la galería de su amigo. Ese año integró allí la exposición colectiva "I2 pintores argentinos" y entre 1916 y 1933 realizó exposiciones individuales casi todos los años. En I9ı6, por consejo médico, se instaló hasta el final de sus días en la provincia serrana de Córdoba, donde produjo sin descanso paisajes puros y poblados por caballos y tipos campesinos. Esta pintura cuadró estupendamente dentro de los cánones del gusto de los burgueses adquiridores tanto por su temática como por su carácter sintético, "abocetado" y sus fuertes empastes matéricos, que llevaron a asimilarlo — forzadamentecon el impresionismo. ${ }^{35}$

Según describen los testigos contemporáneos, Fader era un hombre menudo que lucía la cara roja por pasar tanto tiempo a la intemperie y el cabello "partido al medio en nutridas crenchas hasta más debajo de las orejas". Se distinguía por el gesto hosco acentuado por la boca apretada que, sumado a la lentitud de sus movimientos, le daba una apariencia campesina. ${ }^{36}$ Palabras como "rebelde", "atormentado", "huraño" e "irascible" se repiten al tratar de describir su temperamento, así como también se destacaban sus dotes de trabajador febril.

Con estas cualidades se mostraba en sus fotos de juventud, que lo retratan recién llegado de Europa, y también en las tomadas hacia la segunda década del siglo, como aquellas con las que la revista Plus Ultra ilustraba un reportaje realizado por el también artista y amigo de Fader, Enrique Prins (fig. I2). En la composición principal, su figura ha sido recortada y abstraída del fondo al montarla sobre el blanco de la página. El pintor, parado con la paleta y espátula en mano, ${ }^{37}$ delante de su atril portátil sobre el que se observan los primeros esbozos de un paisaje serrano, aparece asociado a su imagen de "artista de campaña”. Viste uno de los típicos atuendos entonces de moda para la práctica del deporte o el motociclismo: una chaqueta de grandes bolsillos a juego con el pantalón abultado y a la rodilla con polainas de cuero y el infaltable cham-

35. Por ejemplo, Miguel Ángel Cárcano lo caracteriza como "el pintor de la luz en movimiento", asimilando su obra a la de Manet: $c f r$. "Los paisajes de Fader", La Nación, Buenos Aires, 8 de noviembre de I9I8, p. 6.

36. Ibidem, pp. 8 у 2 I.

37. El hecho de llevar la espátula no es un detalle menor, ya que Fader se distinguía precisamente por no usar pinceles y trabajar principalmente con espátula, lo que resultaba en obras de gran carga matérica. 
I2. "Con Fernando Fader", Plus Ultra, año 2, núm. I2, abril de I9I7, s.p.

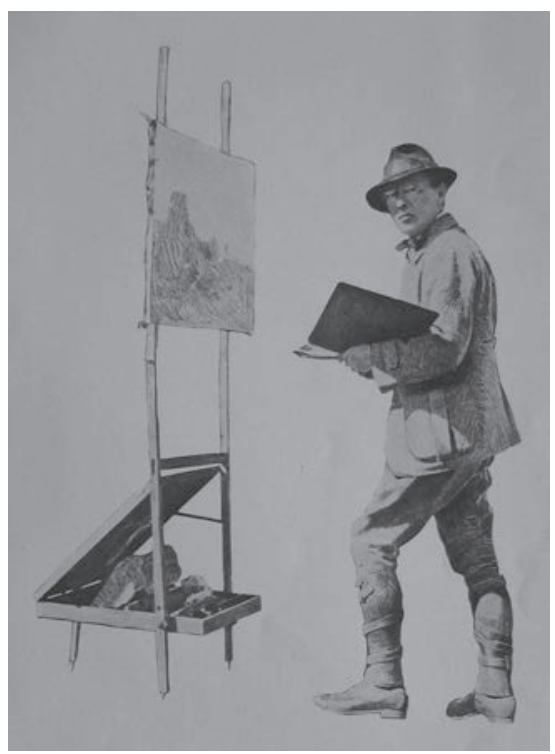

bergo de ala estrecha con que se le retrataba hacia estos años. ${ }^{38}$ En las otras fotos, más pequeñas, se le ve cargando dos inmensos bastidores entre las sierras y haciendo un alto en la realización de una pintura junto a los paisanos y la vaca que le servían de modelos. Las imágenes presentaban este doble perfil que el artista practicaba por aquel entonces y que resultaría en el gran éxito mercantil de su pintura: por un lado, el pintor "nacional" que logra plasmar en las telas una relación empática con el paisaje y la geografía serrana y, en paralelo, el artista europeo y moderno, formado en Alemania, que se profesionaliza y trabaja sin descanso para satisfacer la demanda del público por su pintura. ${ }^{39}$

Esta silueta termina de ratificarse en la serie de autorretratos que Fader pinta hacia la segunda y la tercera décadas del siglo, en los que aparece con el infaltable chambergo y el rostro de frente con la mirada fija en el espectador. En el primero y más grande de ellos (fig. I3), si bien se distingue su gesto característico de los labios hacia abajo, todavía se trata de un vital y joven pintor en

38. Enrique Prins, "Con Fernando Fader", Plus Ultra, Buenos Aires, año 2, núm. I2, abril de 1917 .

39. Cfr. Diana B. Wechsler, "Paisaje, crítica e ideología", en Ciudad-campo en las artes en Argentina y Latinoamérica, Buenos Aires, Centro Argentino de Investigadores de Arte, I99I, pp. 342-350. 


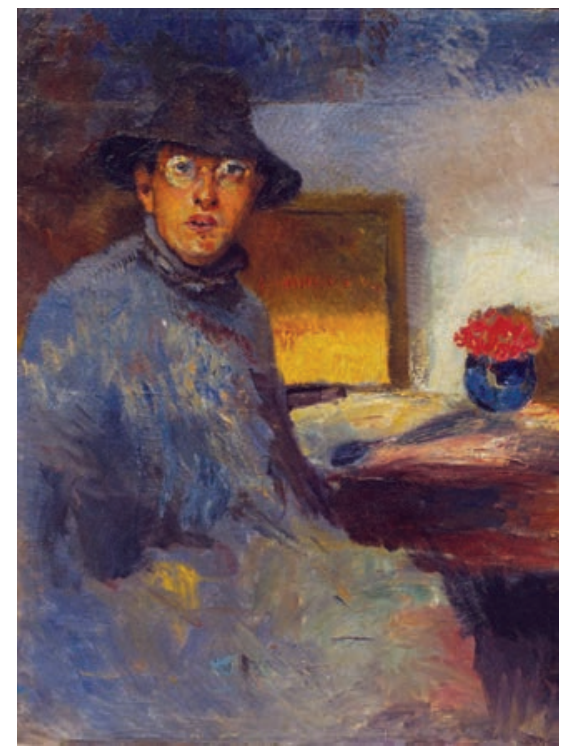

I3. Fernando Fader, Autorretrato, I9I4, óleo sobre tela, I00 $\times 80 \mathrm{~cm}$, Córdoba, Argentina, Museo Provincial de Bellas Artes Emilio Caraffa.

una especie de reconcentrada pausa del trabajo. ${ }^{40}$ Detrás se observan detalles de un bastidor, un pequeño jarrón con flores rojas y lo que se adivina como una paleta. Los colores, saturados y estridentes, producen un fuerte contraste entre los naranjas del rostro y los azules que se repiten en el delantal del artista y en el fondo. El carácter non finito de su vestimenta refuerza asimismo esta idea de fusión entre el personaje y su entorno.

En Autorretrato con barba, realizado en 1922 (fig. I4), Fader porta sombrero de fieltro color arena y un poncho, vestimenta habitual utilizada para protegerse de los fríos que azotaban las mañanas cordobesas en las que le gustaba salir a pintar. Sin embargo, lo que más llama la atención en este retrato es lo curtido y áspero del rostro, efecto logrado con base en los tierras oscuros y los empastes muy cargados. Evidentemente, la vida rústica había dejado huella en la apariencia del pintor, o al menos es así como eligió representarse en esta ocasión. Esta idea se vuelve aún más palpable en el autorretrato de 1925 (fig. I5), donde la cara realizada con naranjas y azules y recortada por las sombras plenas que arroja el sombrero se ha convertido en una suer-

40. Tanto el Museo Provincial de Bellas Artes Emilio Caraffa como la monografía editada con motivo de la exposición de Fader en el MNBA — en 1988 — datan este retrato en I9I4. 
I4. Fernando Fader, Autorretrato con barba, I922, óleo sobre tela, $40 \times 38 \mathrm{~cm}$, Buenos Aires, Museo de Artes Plásticas Eduardo Sívori.

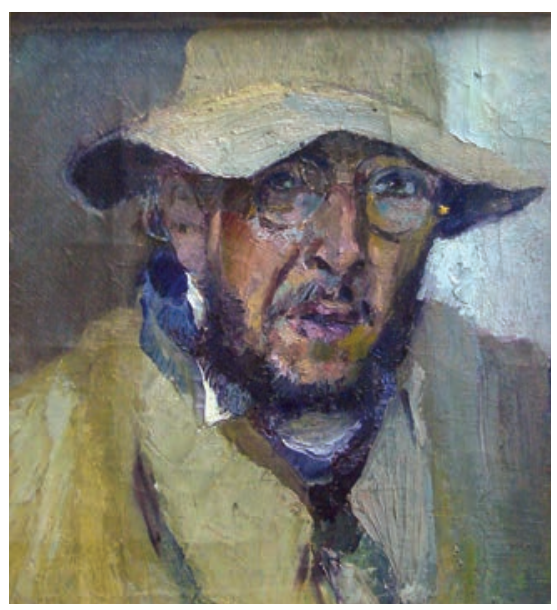

te de máscara. Serio, con el rictus tenso de su boca, Fader parece achinar los ojos para enfocar mejor la vista en el observador del cuadro. La pintura apuesta por la pincelada gruesa y los fuertes contrastes tonales que la vuelven mucho más dramática y, por ende, menos plácida que los paisajes realizados entonces. Esta solución, suponemos, apuntaba a representarlo como el artista batallador y solitario que se ha sumergido en el frío helado o el sol rajante de las sierras para pintar, en un entorno de soledad que entonces se había vuelto más acuciante debido a las desavenencias económicas y el alejamiento de su marchand histórico Müller, quien se encontraba en Europa para arreglar asuntos personales.

Es pertinente señalar que los autorretratos de Fader nunca fueron incluidos en las exposiciones públicas realizadas durante su vida: ni en los envíos a los salones provinciales ni en las exposiciones periódicas de Müller ni siquiera en las muestras-homenaje organizadas en Rosario y Buenos Aires en 1932. Reservados para la esfera íntima, con el fin de pasar el rato cuando el mal tiempo impedía salir a concretar las campañas de pintura, estos autorretratos funcionaban como terrenos de indagación plástica a la vez que habilitaban la proyección más personal del ser artista, aquella que se jugaba en las horas muertas de la domesticidad ruda de la vida serrana, arreciada por el frío, el viento, la salud precaria y fundamentalmente por el aislamiento del mundo del arte y los artistas. 
I96 MARÍA ISABEL BALDASARRE

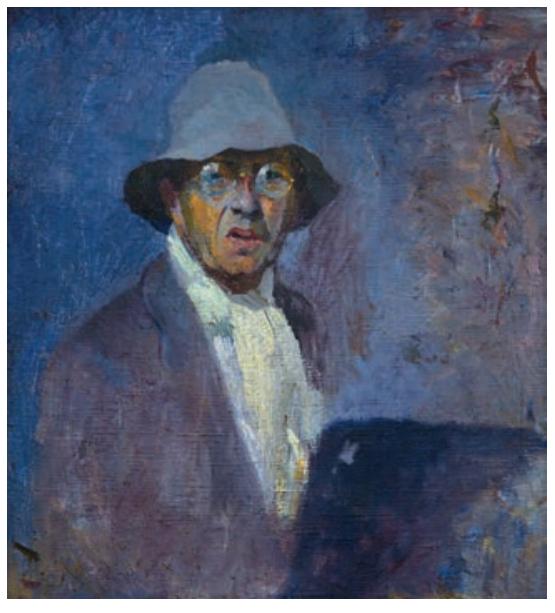

I5. Fernando Fader, Autorretrato, 1925, óleo sobre tela, $75 \times 65 \mathrm{~cm}$, Rosario, Museo Municipal de Bellas Artes Juan B. Castagnino + macro.

\section{Pettoruti}

Mayor contraste aparece entre el autorretrato y las obras realizadas contemporáneamente por el último de los artistas que cierra nuestro recorrido: Emilio Pettoruti (1892-I97I). Becario del gobierno en Europa, Pettoruti viajó en I9I3 a Florencia, donde entró en contacto con Marinetti y los pintores futuristas. Residió luego en Milán, con eventuales estadías en Roma, Múnich y París, donde tuvo ocasión de vincularse también con artistas metafísicos, cubistas y aquellos que luego serían conocidos como del novecento italiano. ${ }^{4 \mathrm{I}}$ En sintonía con estos nuevos lenguajes, Pettoruti participó en las capitales artísticas de muchas exhibiciones de "arte nuevo". Las fotos tomadas en ese contexto lo muestran sonriente, junto con sus compatriotas americanos o sus pares europeos, alineado con las poses de la bohemia que entonces cultivaban los artistas de su círculo. En este ambiente, Pettoruti realizó en I9I8 (fig. I6) un autorretrato que constituye un claro ejemplo de la pintura rupturista que ejercitó hacia esos años y que lo acercó a los planteos compositivos del futurismo, un movimiento al que nunca se adscribió de modo programático, pero en cuyo

4I. Para la reconstrucción de su periplo en Europa, $c f r$. Cayetano Córdoba Iturburu, Pettoruti, Buenos Aires, Academia Nacional de Bellas Artes, I980, y Diana B. Wechsler, "Pettoruti, Spilimbergo, Berni: Italia en el iniciático viaje a Europa”, en Diana B. Wechsler (coord.), Italia en el horizonte de las artes plásticas. Argentina, siglos XIX y XX, Buenos Aires, Asociación Dante Alighieri, 2000, pp. I50-I64. 
I6. Emilio Pettoruti, Autorretrato, I918, óleo sobre hardboard, $54 \times 40 \mathrm{~cm}$, Buenos Aires, Colección Museo Nacional de Bellas Artes D.R. (C) Fundación Pettoruti, www.pettoruti.com.

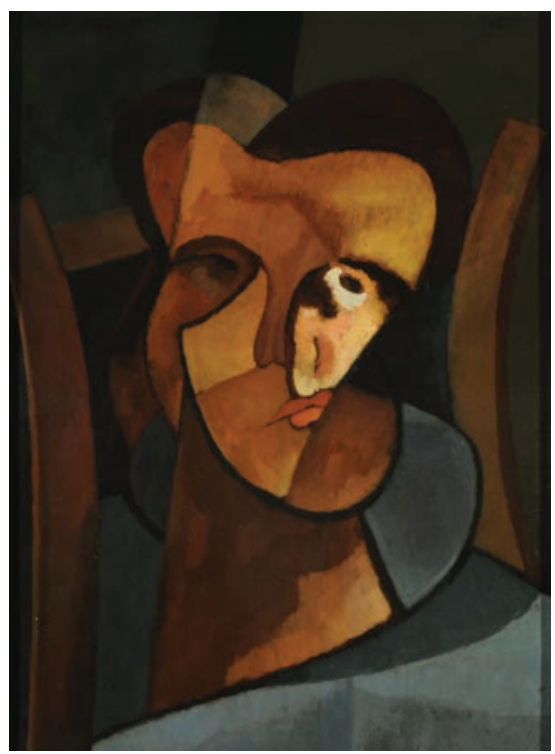

marco estableció diálogos plásticos con sus principales cultores. En el cuadro, los rasgos de su rostro se descomponen a partir del facetamiento de planos acentuados por el contraste de áreas de luz y sombra. ${ }^{42}$ Compuestos a partir de diagonales, curvas y una espiral desplegada en profundidad, los rasgos fisonómicos se sintetizan y esencializan dificultando la posibilidad de identificarlo como un autorretrato del pintor. ${ }^{43}$

Dos años después, los planos de color también contribuyeron a componer el rostro de su amigo El pintor argentino Xul Solar, a quien conoció en Florencia en I9I4 y que, al igual que él, se encontraba ávido de nuevas corrientes estéticas en su largo tránsito por Europa (fig. I7). Con un planteo ahora fundamentalmente ortogonal, las formas geométricas en colores tierras y amarillos y el bermellón reservado para los labios se van superponiendo y así aluden a algunos rasgos de un rostro que, si no fuera por el título, difícilmente

42. Emilio Pettoruti, Autorretrato, 1918, óleo sobre hardboard, $54 \times 40 \mathrm{~cm}$, MNBA.

43. "Individuality can no longer be contained within the terms of manifest personality traits" ("La individualidad no puede ser ya contenida dentro de rasgos de personalidad manifiestos"), postula John Berger respecto del retrato cubista; $c f r$. "The Changing View of Man in the Portrait", en Selected Essays and Articles. The Look of Things, Harmondsworth, Penguin Books, I972, p. 4I. 
198

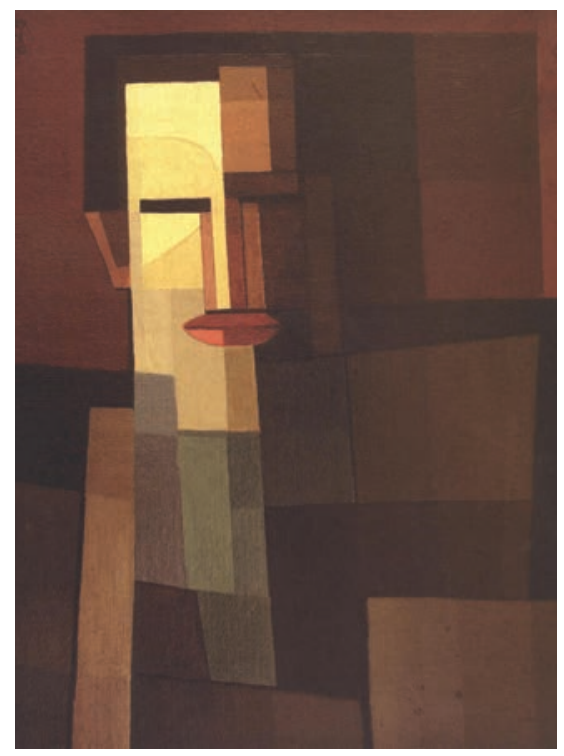

MARÍA ISABEL BALDASARRE
17. Emilio Pettoruti, El pintor argentino Xul Solar, I920, óleo sobre cartón, $55 \times 43 \mathrm{~cm}$, Rosario, Colección Museo Municipal de Bellas Artes Juan B. Castagnino + macro. D.R. (C) Fundación Pettoruti, www.pettoruti.com.

reconoceríamos como perteneciente a su amigo argentino. Ambas obras son testimonio de la experimentación llevada adelante por el pintor en torno a los lenguajes plásticos contemporáneos: las composiciones futuristas y los planteos del cubismo sintético. Pero además, ambos retratos pueden interpretarse como autos de fe en aquella pretensión compartida por Pettoruti y Xul Solar por "abandonar el 'anecdotismo' vigente en la pintura argentina". ${ }^{44}$

En 1924, Pettoruti irrumpió estratégicamente en el medio de Buenos Aires con una exposición individual realizada en la galería Witcomb, que incluyó gran parte de sus obras asociadas con las poéticas futuristas y cubistas. La muestra fue ignorada por algunos medios de prensa, criticada duramente por otros y levantada como estandarte por quienes se sentían sus compañeros en esta búsqueda de renovación estética. ${ }^{45}$ No obstante, puede afirmarse que el

44. Patricia M. Artundo, "El viaje dentro del viaje, o sobre la transitoriedad de los lugaresdestino", en Artistas modernos rioplatenses en Europa I9I I-1924. La experiencia de la vanguardia, Buenos Aires, Fundación Eduardo F. Constantini, 2002, p. I9.

45. Diana B. Wechsler, "Crítica y arte de vanguardia", en Papeles en conflicto. Arte y critica entre la vanguardia y la tradición. Buenos Aires (1920-30), Universidad de Buenos AiresInstituto de Teoría e Historia del Arte Julio E. Payró/Facultad de Filosofía y Letras (Serie Monográfica, 8), 2003. 
I8. "El pintor Emilio Pettoruti", Atlántida, año 6, núm. 253, 8 de febrero de 1923 , s.p.

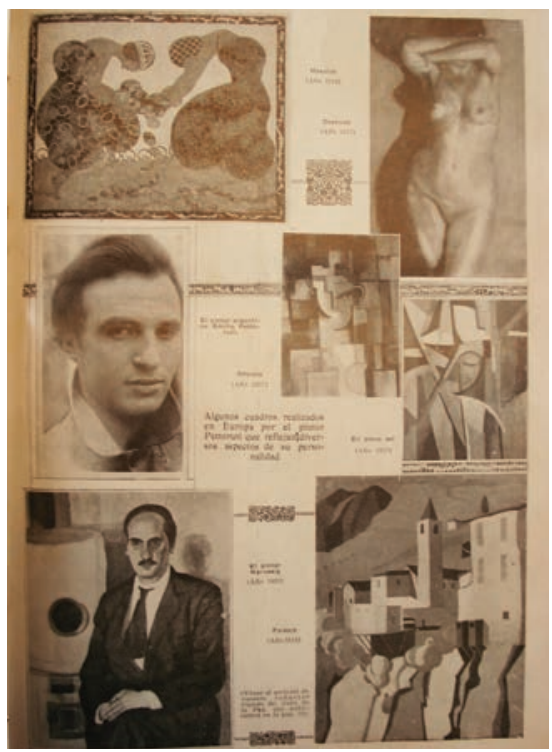

medio fue en general adverso a esta primera táctica de inserción del artista y halló en el humor y la burla un modo de enfrentar la incomprensión ante estos lenguajes novedosos. ${ }^{46}$

Como bien sintetizó el diario La Nación: "la obra última de Pettoruti no es accesible a nuestro medio" y — lo que era más significativo- la crítica reconocía que el pintor era consciente del terreno yermo en que venía a instalar su exposición:

Entre nosotros, para quienes no han vivido largos años en Europa y asistieron allá a los cambios más o menos bruscos del "punto de vista", la obra de Pettoruti no será fácilmente comprensible. Él no lo ignora. Sabe, que sus cuadros no se han hecho para agradar hoy, por lo menos. ${ }^{47}$

Anunciando su llegada, la revista Atlántida publicó en 1923 un conjunto de sus pinturas en compañía de una fotografía del artista (fig. I8). En ella, Pettoruti se mostraba con mirada seductora, algo despeinado, vistiendo un gabán

46. Cfr. Córdoba Iturburu, op. cit., p. 42.

47. "Exposición Emilio Pettoruti", La Nación, Buenos Aires, 28 de octubre de 1924, p. 4. 
abrochado al cuello con las solapas levantadas. Estaba lejos de una pose formal, pero era evidente que la toma había sido muy cuidada y planeada por el artista. ${ }^{48}$

Ya en Buenos Aires, en 1925, produjo un autorretrato que parecía en las antípodas tanto del realizado siete años antes como del espíritu romántico y seductor con que coqueteaban las fotografías recién señaladas (fig. 19). En este cuadro, el artista no olvidó completamente la lección de las vanguardias, pero se alejó de las composiciones más "abstractizantes" de planos de color que había presentado un año antes en Witcomb. De hecho, esta convivencia de cuadros abstractos o de un lenguaje más sintético con otros de una figuración renovada había sido también un aspecto recurrente en su producción europea.

Frente a un fondo neutro, la cara de Pettoruti se distingue por los planos facetados de luz y sombra que van construyendo su rostro y su cuello cilíndrico que se inserta en un suéter abotonado. El tiempo parece haberse detenido en esta pintura. El protagonista no está realizando acción alguna y su cara tampoco transmite emoción discernible; el pintor no hace otra cosa que estar allí, posar y diluirse como sujeto para constituirse en objeto específico del retrato. Subyace en la obra una fuerte composición geométrica y un manejo sintético de la luz. Es decir, la pintura sigue testimoniando la impronta de las búsquedas formales de las vanguardias, pero el resultado obtenido es un retrato mucho más legible, reconocible y claro que el realizado en I9I8. Quizá la elección de estos recursos plásticos se justificaba en el entorno para el que había sido pensada la obra. De acuerdo con lo que el pintor cuenta en su autobiografía, el Autorretrato constituía un estudio para una gran tela que reuniría los rostros de toda su familia. ${ }^{49} \mathrm{Si}$ bien podemos pensar que su círculo más inmediato era receptivo a la vertiente más abstracta de su pintura - y esta hipótesis se refuerza a la luz del retrato eminentemente sintético de su hermana Carolita, realizado ese mismo año de 1925 - , $^{\circ 0}$ a la hora de presentarse ante los suyos al regreso de Europa resultó más viable la "actitud

48. Del mismo modo, la monografía de Alberto M. Candiotti, publicada ese mismo año, empezaba con un retrato suyo que, vistiendo traje y mońo, miraba directamente el objetivo en un gesto indudablemente seductor; $c f r$. Alberto M. Candiotti, Pettoruti, Berlín/Buenos Aires, Internacional, I923.

49. Pettoruti, Un pintor ante el espejo, op. cit., p. 201.

50. Pettoruti ejecutó hacia esa fecha dos retratos de Carolita, nos referimos aquí al más sintético, realizado sobre madera, reproducido en su autobiografía, ibidem, p. 208. 
I9. Emilio Pettorutti, Autorretrato, I925, óleo sobre cartón, $50 \times 40 \mathrm{~cm}$, Buenos Aires, Colección Fundación Pettoruti D.R. (C) Fundación Pettoruti, www.pettoruti.com.

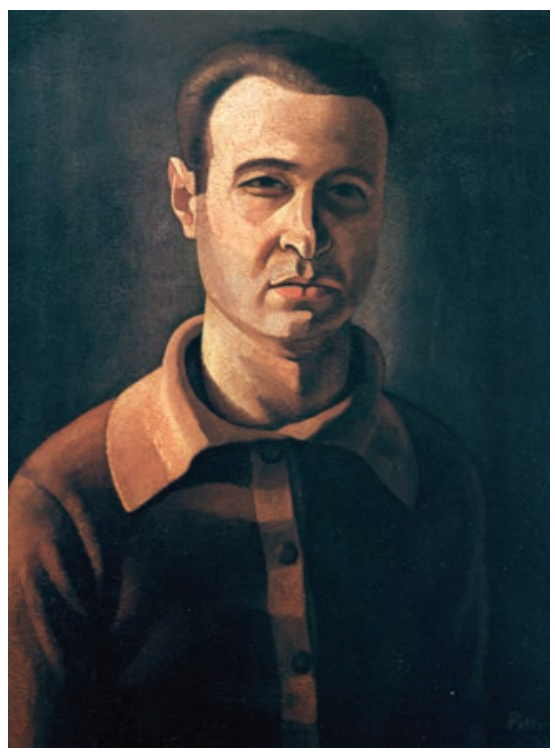

objetiva”, tal como caracterizó a estas obras el crítico Julio E. Payró. ${ }^{\text {I }} \mathrm{Y}$ es entonces donde este autorretrato se enlaza con los objetivos más vastos que Pettoruti enfrentó en esos años y en los subsiguientes, los cuales apuntaban a mediar, infiltrarse y negociar dentro de los espacios de institucionalización del arte más que a limitarse a irrumpir desde un lugar meramente de oposición. ${ }^{52}$

La multiplicidad de recursos con que Pettoruti se configuró en las fotografías y los autorretratos condensaba no sólo los "distintos aspectos de su personalidad" — tal como señalaba el epígrafe de las fotografías reproducidas por Atlántida - sino los diversos modos de inserción en un medio en el que la fuerza de la avanzada vanguardista debía dosificarse ante la precariedad y la corta historia de los espacios a los cuales oponerse.

5I. Julio E. Payró, Emilio Pettoruti, Buenos Aires, Poseidón, 1945, p. 5 I.

52. El texto de Diana B. Wechsler es un trabajo señero para esta lectura de los proyectos llevados a cabo por Pettoruti; véase "Buenos Aires, 1924: trayectoria pública de la doble presentación de Emilio Pettoruti", en VI Jornadas de Teoría e Historia de las Artes: El arte entre lo público y lo privado, Buenos Aires, Centro Argentino de Investigadores de Arte, 1995, pp. $23 \mathrm{I}-240$. 


\section{Coda}

Los casos que ha recorrido este artículo muestran cómo los carriles visuales de la autorrepresentación — fotografías y pinturas - desempeñaron un papel a la hora de constituir y consolidar las carreras de los artistas. Y además ayudan a pensar cómo artistas cuyas elecciones estéticas han sido ubicadas por la historiografía en lugares antitéticos — los figurativos y evocativos Fader y Quirós frente al vanguardista Pettoruti- transitaron contemporáneamente por el proceso de profesionalización de las artes y tuvieron el objetivo común de vivir de su producción plástica, proyecto en que para todos la imagen de sí mismos desempeñó un papel fundamental. Ella no sólo acompañó este proceso al volverlo visible, sino que la imagen propia también proporcionó la arena en que el artista ensayó sus posibilidades de presentarse como pintor o escultor, en un momento en que la práctica del arte pasaba de ser una ocupación de pocos a una profesión redituable.

Los creadores adhirieron a tipologías de cómo ser artista y construyeron nuevas maneras que a su vez serían seguidas por otros, no sólo en los retratos, sino también en las fotos. De los gentlemen decimonónicos, pasando por algunos casos que trataban de escapar de estas representaciones distinguidas y acercándose al artista bohemio u obrero, las imágenes de principios del siglo xx los muestran en general como personajes más mundanos, incluso asimilables a los hombres y mujeres modernos que consumían el tipo de publicaciones en las que aparecían sus fotografías; aunque el garbo, el desparpajo o cierto aire evasivo seguirían funcionando como atributos necesarios y esperables en todo cultor de las bellas artes.

Al estar bajo la entera decisión de los artistas, los autorretratos conllevan aún más tomas de posición de sus realizadores. Ellos no sólo deben elegir la pose, el escenario y los atributos que mejor los representan sino - lo que es quizá más importante- discriminar dentro de su lenguaje distintivo aquellos recursos plásticos más funcionales para transmitir la subjetividad perseguida en cada retrato. Ésta es una búsqueda que no se da completamente de forma consciente, pero en la que hay selecciones voluntarias que se juegan en el proceso creativo del artista y que terminan de configurarse a partir de los usos sociales que se abren en la circulación pública de las obras. Así, podemos pensar estas imágenes como parte de un proceso de construcción del estatus del artista que se inicia en el taller o en el estudio del fotógrafo teniendo en mente cuál será el público receptor de esa obra, pero que ter- 
DOI: http://dx.doi.org/10.22201/iie.18703062e.2012.100.2330

REPRESENTACIÓN Y AUTORREPRESENTACIÓN EN EL ARTE

mina de configurarse en el momento en que la obra adquiere dimensión pública.

Las fotografías analizadas hacen perceptibles las fórmulas viables de ser artista, que en mayor o menor medida debían tener algo de elegante, burgués, mundano, sofisticado, inaccesible, culto y moderno. En los autorretratos analizados se suma además un componente de gesta, de lucha, y quizá de soledad, implícito en llevar adelante no sólo el proceso creativo individual sino la institucionalización de un espacio para las artes en el país. ‘

* Artículo recibido el I9 de octubre de 20 Io, aceptado al I 8 de agosto de 20 I I. 